III. FOREST ECOLOGY AND BIOLOGY

\title{
ECOLOGICAL-PHYTOGEOGRAPHIC CHARACTERISTICS OF THE MAIN EDIFICATORY SPECIES IN THE FORESTS OF LOZENSKA MOUNTAIN
}

\begin{abstract}
Plamen Glogov, Mira L. Georgieva
Abstract. The study covers Phase 2 of the ecological-phytogeographic analysis of the dendroflora of Lozenska Mountain. Its purpose is to characterize 15 species-edificators of tree and shrub communities in the mountain and to point out the indicators that most determine the assessment of their ability to long-term adaptability to mountain conditions (convertibility). The performed characterization of the edificators with respect to the reference species shows some heterogeneity in the influence of the factors and the distribution of the groups of species. Indicators, which determinate the most convertibility assessments of edificators are cryoclimatic factor, edaphic regimes and soil $\mathrm{pH}$.
\end{abstract}

Keywords: trees, shrubs, dendroflora, evaluation

\section{INTRODUCTION}

In the period of 2018-2020, a number of studies were conducted on the dendroflora in the territory of the Lozenska Mountain in terms of its taxonomic structure [6], phytogeographic [7], ecological [9] and economic characteristics $[4,8]$. The results of these studies were part of Phase 1 of the multifactor ecological-phytogeographic analysis of the dendroflora of Lozenska Mountain. The remaining two stages are related to the complex characterization of the edificatory species on the mountain (Stage 2) and the assessment of their convertibility (Stage 3) [5].

The aim of this publication is to implement stage 2 from the analysis of the dendroflora of Lozenska Mountain - a characteristic of the main edificatory species involved in the tree and shrub communities in the study area and to specify the indicators that most determine the assessments of their convertibility.

\section{MATERIALS AND METHODS}

Lozenska Mountain is an independent part of Ihtimanska Sredna Gora with an area of about 80 $\mathrm{km}^{2}$ and an altitude of $1190 \mathrm{~m}$. Its main ridge of the mountain is west-east oriented. The mountain pertains to the Transition Climate Zone, which is characterized by relatively mild winters, low annual temperature amplitudes and two annual precipitation maximums [18]. The rivers on the territory of the mountain have an inconstant water regime, but in the immediate vicinity of the mountain pass the river Iskar as well as "Pancharevo", "Pasarel" and "Iskar" dams and the lakes of Gabra village.

Forest areas are occupied by two major soil types - Cinnamon Forest soils (Chromic Luvisols) and Brown Forest soils (Dystric-Eutric Cambisols) [15]. Their characteristics are similar to the
Cambisols and Umbrisols soil groups in the World Reference Base for Soil Resources [10]. Cinnamon Forest soils (Chromic Luvisols) typically develop only in the belt of xerothermic oak forests. They typically reach 700-800 $\mathrm{m}$ a.s.1. The soils of the sites occupied by the mesophyte oak belt (Quercus daleshampii Ten. from 800 to $1100 \mathrm{~m}$ ) are transitional to the unsaturated Brown Forest soils 5 (Dystric-Eutric Cambisols). The habitats of typical Brown Forest soils (Dystric-Eutric Cambisols) are occupied by clear beech and, in some places, by mixed beech-hornbeam forests (between 900 and $1100 \mathrm{~m}$ ) [13]. Their properties vary depending on the relief, respectively on exhibitions with the northern component, soils are deep and rich, while on the southern exhibitions they are shallow and poor [2].

The methodology of analysis and evaluation follows the approaches of $[5,11,12,17]$. The edificatory species in the study area are evaluated by phytogeographical and ecological indicators according to their belonging to a particular group and for each species was given a summarized evaluation by the scale presented in Table 1. For comparison with all other edificatory-species, the "reference species" is introduced, the indicators of which coincide with the prevailing for each of the groups in the established dendrofloristic composition of the studied territory. The determinants of the convertibility assessment are the indicators (phytogeographical and environmental), which are the biggest reason why the estimation of a given edificator differs from that of the reference species.

In 2019 some of the analysis materials were obtained from Joint Project Database No. CB007.2.32.170 "For everyone saved a tree (FOREST)" co-funded by the European Union through the Interreg-IPA Bulgaria-Serbia Cross-border Cooperation Program 2014 - 2020 (FOREST, 2019) 
Table 1. Scale of participation of groups by individual indicators

\begin{tabular}{|c|c|}
\hline Rating & Participation of the group of species in the established dendroflora composition \\
\hline 1 & The group is represented by 1 species from the established dendroflora list; \\
\hline 2 & $\begin{array}{c}\text { The group is represented by species participation of up to 10\% of the established dendroflora } \\
\text { composition; }\end{array}$ \\
\hline 3 & $\begin{array}{c}\text { The group is represented by the participation of species between } 11 \text { and } 30 \% \text { of the established } \\
\text { dendroflora composition; }\end{array}$ \\
\hline 4 & $\begin{array}{c}\text { The group is represented by the participation of species between } 31 \text { and } 50 \% \text { of the established } \\
\text { dendroflora composition; }\end{array}$ \\
\hline 5 & $\begin{array}{c}\text { The group is represented by the participation of species over 50\% of the established dendroflora } \\
\text { composition; }\end{array}$ \\
\hline
\end{tabular}

\section{Legend of abbreviations used in the text:}

Floristic elements by [19]: Med- Mediterranean; Eur- European; Boreal- species characteristic of the taiga and distributed in the mountains in the central and southern parts of the Northern Hemisphere; As- Asian; Carp-Carpathian; Bal- Balkan; C- central; Phytogeographical elements (according to [16]): TMC thermophytes from the mediterranean center; TNCC thermophytes from the northern continental center; MMSB - mesotherms and microtherms from the Silvoboreal Center; TMMM - thermophytes, mesotherms and microtherms from the mountain center; 1 - stationary element; 2- mobile - (incl. secondary element; Ecological groups (according to [14]) in accordance to their distribution: Thermoclimatic regime: $\mathrm{sCE}$ - sub-Central European species; SCE - South-Central European species; CR - cold-resistant species; Ombroclimatic regime: Opb - orthopolybionts; Sasb - subarid stenobionts. Cryoclimatic regime: Opb orthopolybionts; SMW - stenobionts of mild winters, PMW - polybionts of the moderate winters. Water regime of the soil: MsPf-mesopolyphytes; Ms mesophytes; XeMs - xeromesophytes; HgMs hygromezophytes; MsHg - mesohygrophytes; MsXe mesoxerophytes. Nutritional regime of the soil: MMT mesomegatrophs; MOT - meso-oligotrophs; MPT mesopolitrophs; MT-mesotrophs. pH of soil solution: Alpb - alkaliphilic polybionts; Evr Evribionts; sEvr - subevribionts. Regime of sunlight: HpHe-hypoheliophytes; HmSc - hemisciophytes; Sc - sciophytes; He - Heliophytes. Eco-groups in complex by thermoclimatic and altitudinal ranges: Tlmn-Translowmountainous, Pmn-pre-mountainous, Hmn-high-mountainous.

\section{RESULTS}

Based on data from latest forestry management projects and studies by [6] the main edificatory species were determined -13 species that are part of the natural tree and shrub communities on the territory of Lozenska Mountain. They occupy 15.3\% of the natural dendroflora of the mountain, which consists of 85 species according to [6]. The following tree and shrub species have been identified as dominant in natural forest phytocoenoses: Quercus pubescens Willd., Quercus cerris L., Quercus frainetto Ten., Quercus dalechampii Ten., Carpinus betulus L., Fagus sylvatica L., Carpinus orientalis Mill, Tilia tomentosa Moench., Coryllus avelana L., Syringa vulgaris L., Fraxinus ornus L., Juniperus communis L., Amygdalus nana L. The number of edificators is very similar to that indicated in an investigation of the mountain vegetation done 60 years ago by [3]. In the present study Tilia tomentosa was additinaly included in the edificators' list, which communities cover about $1.2 \%$ of the mountain area and are located mainly in the southwestern part of the mountain in the gorge of Iskar River. Scots pine (Pinus sylvestris L.) and European black pine (Pinus nigra Arn.) are edificators of artificial communities that occupy a significant area (about 9.7\%) of the mountainous area, their characteristics and the assessment of the convertibility of these species are related with prognoses of their replacement by indigenous oak vegetation, as well as by processes such as drying in coniferous forest.

For each of the edificatory species, a characteristic of the individual phytogeographical and ecological indicators was performed, with the assessment of their belonging to a particular group and a summary rating was presented on the scale of Table 1. For comparison with all other edificators, a "reference species" was introduced (Table 2), the indicators of which coincide with the prevailing indicators for each of the groups with the established dendroflora composition on the territory of the mountain. 
Table 2. Complex assessment (maximum possible) of the reference species by the sum of ecological-phytogeographic indicators

\begin{tabular}{|c|c|c|c|}
\hline Phytogeographical and Ecological groups & $\begin{array}{c}\text { Indicators of } \\
\text { Reference species }\end{array}$ & Predominant group & $\begin{array}{c}\text { Assessment against the } \\
\text { predominant group of species by } \\
\text { individual indicators }\end{array}$ \\
\hline Floral elements & SubMed & SubMed & 3 \\
\hline Phytogeographical Elements & $1 \mathrm{TMMM}$ & $1 \mathrm{TMMM}$ & 4 \\
\hline Thermal-climate eco-groups & sCE & sCE & 4 \\
\hline Ombro-climatic eco-groups & Opb & Opb & 5 \\
\hline Cryo-climatic eco-groups & Opb & Opb & 4 \\
\hline Zonal Eco-Groups toward altitude & Pmn & Pmn & 5 \\
\hline Eco-groups toward water regime of the soil & $\mathrm{Ms}$ & $\mathrm{Ms}$ & 5 \\
\hline Eco-groups toward soil nutrition & $\mathrm{MMT}$ & $\mathrm{MMT}$ & 4 \\
\hline Eco-groups toward acidity & $\mathrm{Alpb}$ & $\mathrm{Alpb}$ & 5 \\
\hline Eco-groups toward lighting & $\mathrm{HpHe}$ & $\mathrm{HpHe}$ & 43 \\
\hline \multicolumn{2}{|c|}{ Overall assessment } & & 5 \\
\hline
\end{tabular}

The ecological-phytogeographic characteristic of the reference species shows predominantly average values of the indicators, i.e. it is not the type of the ultimate regimes. Its total estimate is not maximal on the scale - 50 , but is 43 , since the estimates of most of the indicators are less than 5 , which means that with regard to these indicators, a strong and heterogeneous influence of various factors and plant groups in ecological and phytogeographic relation is felt on the territory of the mountain.

Tables 3-5 present the estimates of the complex ecological-phytogeographic indicators of the unidentifiable species relative to the reference species.

Table 3. Estimates by Complex Ecological-Phytogeographical Indicators of Edificatory Species of Tree Communities in the Area of Xerothermic Oaks

\begin{tabular}{|c|c|c|c|c|c|c|c|c|c|c|c|}
\hline $\begin{array}{c}\text { Phytogeographical } \\
\text { and ecological } \\
\text { groups }\end{array}$ & \multicolumn{2}{|c|}{ Quercus cerris } & \multicolumn{2}{|c|}{ Quercus frainetto } & Quercus pubescens & \multicolumn{2}{|c|}{ Pinus nigra } & \multicolumn{2}{|c|}{ Pinus sylvestris } \\
\hline & Group & Estimate & Group & Estimate & Group & Estimate & Group & Estimate & Group & Estimate \\
\hline Floral elements & $\begin{array}{c}\text { Eur- } \\
\text { SubMed }\end{array}$ & 3 & Eur & 2 & $\begin{array}{c}\text { Eur- } \\
\text { SubMed }\end{array}$ & 2 & SubMed & 3 & Subboreal & 2 \\
\hline $\begin{array}{c}\text { Phytogeographical } \\
\text { elements }\end{array}$ & $1 \mathrm{TMMM}$ & 4 & $1 \mathrm{TMMM}$ & 4 & $1 \mathrm{TMC}$ & 2 & $1 \mathrm{TMMM}$ & 4 & $1 \mathrm{MMSB}$ & 3 \\
\hline $\begin{array}{c}\text { Thermoclimatic } \\
\text { eco-groups }\end{array}$ & $\mathrm{sCE}$ & 4 & $\mathrm{sCE}$ & 4 & $\mathrm{sCE}$ & 4 & $\mathrm{sCE}$ & 4 & $\mathrm{sCE}$ & 4 \\
\hline $\begin{array}{c}\text { Ombroclimatic } \\
\text { eco-groups }\end{array}$ & $\mathrm{Opb}$ & 5 & $\mathrm{Opb}$ & 5 & $\mathrm{Opb}$ & 5 & $\mathrm{Opb}$ & 5 & $\mathrm{Opb}$ & 5 \\
\hline $\begin{array}{c}\text { Cryoclimatic eco- } \\
\text { groups }\end{array}$ & $\mathrm{SMW}$ & 4 & $\mathrm{Opb}$ & 4 & $\mathrm{SMW}$ & 4 & $\mathrm{SMW}$ & 4 & $\mathrm{PMW}$ & 2 \\
\hline $\begin{array}{c}\text { Zonal eco-groups } \\
\text { toward altitude }\end{array}$ & $\mathrm{Pmn}$ & 5 & $\mathrm{Pmn}$ & 5 & $\mathrm{Pmn}$ & 5 & $\mathrm{Pmn}$ & 5 & $\mathrm{Pmn}$ & 2 \\
\hline $\begin{array}{c}\text { Eco-groups } \\
\text { toward water } \\
\text { regime of the soil }\end{array}$ & $\mathrm{Ms}$ & 4 & $\mathrm{XeMs}$ & 3 & $\mathrm{XeMs}$ & 3 & $\mathrm{Ms}$ & 3 & $\mathrm{HgMs}$ & 3 \\
\hline $\begin{array}{c}\text { Eco-groups } \\
\text { toward soil } \\
\text { nutrition }\end{array}$ & $\mathrm{MMT}$ & 5 & $\mathrm{MMT}$ & 5 & $\mathrm{MMT}$ & 5 & $\mathrm{MPT}$ & 3 & $\mathrm{MOT}$ & 3 \\
\hline $\begin{array}{c}\text { Eco-groups } \\
\text { toward pH }\end{array}$ & $\mathrm{Evr}$ & 4 & $\mathrm{Evr}$ & 3 & $\mathrm{sEvr}$ & 2 & $\mathrm{Alpb}$ & 4 & $\mathrm{Evr}$ & 3 \\
\hline $\begin{array}{c}\text { Eco-groups } \\
\text { toward lighting }\end{array}$ & $\mathrm{HpHe}$ & 5 & $\mathrm{HpHe}$ & 5 & $\mathrm{HpHe}$ & 5 & $\mathrm{HpHe}$ & 5 & $\mathrm{HpHe}$ & 5 \\
\hline
\end{tabular}


Table 4. Estimates by Complex Ecological-Phytogeographical Indicators of the Edificatory Species of Tree and Tree-Shrub Communities in the Hornbeam-Sessile Belt and Beech Belt

\begin{tabular}{|c|c|c|c|c|c|c|c|c|c|c|}
\hline $\begin{array}{c}\text { Phytogeographical } \\
\text { and ecological } \\
\text { groups }\end{array}$ & \multicolumn{2}{|c|}{ Carpinus betulus } & \multicolumn{2}{|c|}{ Quercus daleshampii } & \multicolumn{2}{|c|}{ Fagus silvatica } & \multicolumn{3}{|c|}{ Tilia tomentosa } & \multicolumn{3}{c|}{ Coryllus avelana } \\
\hline & Group & Estimate & Group & Estimate & Group & Estimate & Group & Estimate & Group & Estimate \\
\hline Floral elements & $\begin{array}{c}\text { Eur- } \\
\text { SubMed }\end{array}$ & 3 & SubMed & 3 & Eur & 3 & Eur & 2 & $\begin{array}{c}\text { Med- } \\
\text { CAs }\end{array}$ & 2 \\
\hline $\begin{array}{c}\text { Phytogeographical } \\
\text { elements }\end{array}$ & 1TMMM & 4 & 1TMMM & 4 & $1 \mathrm{TMMM}$ & 4 & $1 \mathrm{TMMM}$ & 4 & $1 \mathrm{MMSB}$ & 3 \\
\hline $\begin{array}{c}\text { Thermoclimatic } \\
\text { eco-groups }\end{array}$ & $\mathrm{sCE}$ & 4 & $\mathrm{SCE}$ & 4 & sCE & 4 & SCE & 4 & sCE & 4 \\
\hline $\begin{array}{c}\text { Ombroclimatic } \\
\text { eco-groups }\end{array}$ & Opb & 5 & Opb & 5 & Opb & 5 & Opb & 5 & Opb & 5 \\
\hline $\begin{array}{c}\text { Cryoclimatic eco- } \\
\text { groups }\end{array}$ & SMW & 4 & Opb & 4 & SMW & 4 & SMW & 4 & PMW & 2 \\
\hline $\begin{array}{c}\text { Zonal eco-groups } \\
\text { toward altitude }\end{array}$ & Pmn & 5 & Pmn & 5 & Tlmn & 5 & Hmn & 2 & Pmn & 5 \\
\hline $\begin{array}{c}\text { Eco-groups } \\
\text { toward water } \\
\text { regime of the soil }\end{array}$ & Ms & 4 & MsPf & 4 & Ms & 4 & HgMs & 3 & XeMs & 3 \\
\hline $\begin{array}{c}\text { Eco-groups } \\
\text { toward soil } \\
\text { nutrition }\end{array}$ & MPT & 3 & MPT & 3 & MPT & 5 & MMT & 5 & MMT & 5 \\
\hline $\begin{array}{c}\text { Eco-groups } \\
\text { toward pH }\end{array}$ & Evr & 3 & sEvr & 2 & Evr & 4 & Alpb & 3 & Evr & 3 \\
\hline $\begin{array}{c}\text { Eco-groups } \\
\text { toward lighting }\end{array}$ & Sc & 2 & HpHe & 5 & Sc & 5 & HmSc & 2 & HmSc & 3 \\
\hline
\end{tabular}

Table 5. Estimates by Complex Ecological-Phytogeographical Indicators of Edificatory Species from Xerothermal and Intrasonal Tree and Tree-Shrub Communities

\begin{tabular}{|c|c|c|c|c|c|c|c|c|c|c|}
\hline $\begin{array}{c}\text { Phytogeo- } \\
\text { graphical and } \\
\text { ecological } \\
\text { groups }\end{array}$ & \multicolumn{2}{|c|}{$\begin{array}{c}\text { Carpinus } \\
\text { orientalis }\end{array}$} & \multicolumn{2}{c|}{$\begin{array}{c}\text { Fraxinus } \\
\text { ornus }\end{array}$} & \multicolumn{2}{|c|}{ Juniperus communis } & \multicolumn{2}{c|}{$\begin{array}{c}\text { Syringa } \\
\text { vulgaris }\end{array}$} & \multicolumn{2}{|c|}{$\begin{array}{c}\text { Amygdalus } \\
\text { nana }\end{array}$} \\
\cline { 2 - 12 } & Group & Estimate & Group & Estimate & Group & Estimate & Group & Estimate & Group & Estimate \\
\hline Floral elements & SubMed & 3 & SubMed & 3 & Subboreal & 3 & $\begin{array}{c}\text { Carp- } \\
\text { Bal }\end{array}$ & 1 & Eur-As & 3 \\
\hline $\begin{array}{c}\text { Phytogeogra- } \\
\text { phical elements }\end{array}$ & $1 \mathrm{TMMM}$ & 4 & $1 \mathrm{TMMM}$ & 4 & $1 \mathrm{MMSB}$ & 4 & $1 \mathrm{TMMM}$ & 4 & $1 \mathrm{TNCC}$ & 2 \\
\hline $\begin{array}{c}\text { Thermoclimatic } \\
\text { eco-groups }\end{array}$ & SCE & 4 & SCE & 4 & CR & 4 & sCE & 4 & sCE & 4 \\
\hline $\begin{array}{c}\text { Ombroclimatic } \\
\text { eco-groups }\end{array}$ & Opb & 5 & Opb & 5 & Opb & 5 & Sasb & 2 & Opb & 5 \\
\hline
\end{tabular}




\begin{tabular}{|c|c|c|c|c|c|c|c|c|c|c|}
$\begin{array}{c}\text { Cryoclimatic } \\
\text { eco-groups }\end{array}$ & SMW & 4 & Opb & 4 & PMW & 4 & SMW & 4 & Opb & 4 \\
\hline $\begin{array}{c}\text { Zonal eco- } \\
\text { groups toward } \\
\text { altitude }\end{array}$ & Pmn & 5 & Pmn & 5 & Tlmn & 5 & Pmn & 5 & Pmn & 5 \\
\hline $\begin{array}{c}\text { Eco-groups } \\
\text { toward water } \\
\text { regime of the } \\
\text { soil }\end{array}$ & XeMs & 4 & Ms & 4 & MsPf & 4 & XeMs & 3 & MsXe & 2 \\
\hline $\begin{array}{c}\text { Eco-groups } \\
\text { toward soil } \\
\text { nutrition }\end{array}$ & MMT & 5 & MPT & 3 & MPT & 5 & MMT & 5 & MMT & 5 \\
\hline $\begin{array}{c}\text { Eco-groups } \\
\text { toward pH }\end{array}$ & Alpb & 4 & Alpb & 4 & Evr & 4 & Alpb & 4 & Alpb & 4 \\
\hline $\begin{array}{c}\text { Eco-groups } \\
\text { toward lighting }\end{array}$ & HpHe & 5 & HpHe & 5 & HpHe & 5 & HpHe & 5 & He & 2 \\
\hline
\end{tabular}

\section{DISCUSSION}

The results presented in Tables 3-5 show that most species partially cover the set of ecological and phytogeographical indicators. Eleven edificatory species (73.3\%) belong to stationary thermophytes, mesotherms and microtherms from the mountain center and only 3 species (20.0\%) are stationary mesotherms and microtherms from the Silvoboreal center. With respect to the entire dendroflora, these two groups of elements retain their predominant participation, but the ratio between them is $45.9 \%$ : $18.8 \%$ according to [7], which shows that, unlike the whole species composition, more than $50 \%$ of the edificators are elements of the mountain center and for most of them the burden of forming the convertibility estimate for this indicator is the same. The distribution of the edificators by floristic elements indicates a strong sub-Mediterranean influence in their distribution. Sub-Mediterranean (5 species, $33.3 \%$ ) and European-sub-Mediterranean (3 species, $20.0 \%$ ) species are predominat, in contrast to the entire dendroflora, in which with the largest participation are European (29.4\%), sub-Mediterranean (24.7\%) and Eurasian (23.6\%) elements [7]. The low assessment of the reference species by this indicator is due to the diversity of floristic elemnts in the mountain, which, due to its tolerance, has little effect on the assessment of the species' convertibility.

In terms of the ecological characteristics of the edificators in reference species observe the highest scores 5 in four of the eco-groups distributed by rainfall (ombroclimatic eco-groups), their complex by altitude and temperature (zonal eco-groups), light and nutrition. The remaining eco-groups (thermoclimatic, cryoclimatic, humidity and acidity of the soil) are rated 4, which means that the total number of species belonging to their dominant group does not exceed $50 \%$ of the entire dendroflora. For the thermoclimate groups in the mountain dendroflora, the ratio between sub-central European species and southern central European species is $47.1 \%: 45.9 \%$ [9]. With respect to the edificatory species, this ratio is in favor of the South- Central European species by 46.7\%: 40.0\%. This equalization of participation does not favor either of the two main groups; therefore, this indicator does not have a drastic effect on the assessment of the convertibility of the edificatory species. In the cryoclimatic factor, the opposite trend is observed - in the mountain dendroflora predominate orthopolybionts $(43.5 \%)$ over stenobionts of the mild winters $(28.2 \%)$ [9], while among edificators stenobionts of mild winters are the dominant group with 46.7\%: 26.7\%. However, unlike the temperature factor, the cryoclimatic groups are not close in terms of participation in the dendroflora and fall within different assessment intervals of Table 1, which is why this factor appears to have a strong influence on the differentiation of species from their total convertibility assessment. The distribution of edificatory species and forest vegetation is generally associated with the adverse effects of winter freezing winds, which are very often more important for the propagation of this vegetation type than the low winter temperature. This is especially true for places 
with repand terrain such as Lozenska Mountain and some hilly areas of Sofia District, where the spread of forest vegetation is sometimes restricted only to the folds of the relief and to the steeper places, better protected by its air currents [16].

In contrast to the cryoclimatic eco-group, the ombroclimatic shows a strong dominance of orthopolybionts, both in terms of the whole dendroflora $(84.7 \%)$ and edificators $(86.7 \%)$ [9], which shows that the rainfall regime is not a determinant of differences in the estimation of convertibility between edificators. The same applies to the distribution of species by altitude and sunlight factors. $73.3 \%$ of the edificators and $60 \%$ of the representatives of the mountain dendroflora belong to the pre-mountain group, and more than half of them $(52.9 \%)$ are hypoheliophytes [9].

According to the water regime of the soil, which determines the content of soil available water by plants [1], in the mountain dendroflora the predominant are the moisture-loving species, with the highest percentage being typical mesophytes $(38.8 \%)$ followed by xeromezophytes $(25.9 \%)$ and hygromezophytes (24.7\%) [9]. For the edificatory species, the ratio between these groups is: $33.3 \%$ : $33.3 \%$ : $13.3 \%$. The close percentages of groups' participation mean that the water regime of the soil is not an indicator of significant differences in the estimates of the edificators.

In the distribution of species by soil acidity, mesomegatrophs represented by $38.8 \%$ in the dendroflora and by $46.7 \%$ of the edificators are with highest percentage [9]. Second in participation in dendroflora are meso-oligotrophs (by 20\%), and mesopolitrophs among the edificators (40\%). The large difference in species participation between the leading and the second groups, and the close percentage of participation between the two leading groups in the edificators, shows that soil nutrition is among the factors with a strong influence in the formation of the final convertibility assessment. In terms of its preference to soil $\mathrm{pH}$, the ratio of species in the major Lozenska mountain dendroflora groups: alkaliphilic polybionts: evribionts: mesoacidophilic polybiots is $38.8 \%$ : 29.4\%: $24.7 \%$ [9], and for edificatory species, this ratio is $33.3 \%$ : $46.7 \%$ : $6.7 \%$. These differences in dominant groups and the low percentage of mesoacidophilic polybiots among the edificators are prerequisites for differences in the estimates of convertibility between species determined by soil acidity.

The highest rates of convertibility, i.e. the species showing the most adaptability to changing mountain conditions, are Carpinus orientalis and Fraxinus ornus. Pinus sylvestris and Juniperus communis have the lowest ratings. The indicators and estimates of none of the edificators do not fully match those of the reference species.

\section{CONCLUSIONS}

The number of edificatory species in the forest communities of Lozenska Mountain has changed slightly over the last 50 years.

The reference species of the study is not the species of extreme environmental regimes.

The performed characterization of the edificators with respect to the reference species shows some heterogeneity in the influence of the factors and the distribution of the groups of species.

The most determinants for the convertibility of the edificators are cryoclimatic factor, edaphic regime and soil $\mathrm{pH}$.

The study is the basis for the last stage (Stage 3) of the multifactor ecological-phytogeographic analysis of the Lozenska Mountain dendroflora related to the evaluation and analysis of the convertibility of the edificatory species.

ACKNOWLEDGMENTS: This publication has been produced with the assistance of the European Union through the Interreg-IPA CBC BulgariaSerbia Program, CCI No 2014TC16I5CB007. The contents of this publication are the sole responsibility of the authors and may in no way be taken to reflect the views of the European Union or the Managing Authority of the Program.

\section{REFERENCES}

1. Bogdanov, S. Soil moisture absorption as a factor in the sustainable development of forests affected by forest fires. Managment and sustainable development. 3, (46), 2014, 23-26. (in Bulgarian).

2. Bogdanov, S., Influence of relief on the forest vegetation properties of brown forest soils. Ecological Engineering and Environment Protection, 3, 2018, 53-57. (in Bulgarian).

3. Ganchev, I. Vegetation of the Lozenska planina and specifics in its development. Publ. House BAN, Sofia, 1961, 193 p. (in Bulgarian).

4. Georgieva, M.L., P. Glogov. Study of the medicine dendrophora the territory of Lozenska mountain. XXVII International conference "Management and quality" for young scientists. $11 \div$ 12 May, Yambol, Bulgaria. 2018, 176-182. (in Bulgarian). 
5. Glogov, P. M. Georgieva, A. Delkov. Complex methodological approach for dendrofloristic research, Forest science, 2, 2017, 3-19. (in Bulgarian).

6. Glogov, P. M. Georgieva, A. Delkov, D. Pavlova, G. Popov. Analysis of dendroflora on the territory of Lozen mountain I. Taxonomic and biomorphological characteristic. Forest science, 1, 2018a, 3-21. (in Bulgarian)

7. Glogov, P. M. Georgieva, D. Pavlova, Y. Dodev. Analysis of dendroflora on the territory of Lozenska mountain. II. Characteristic of phytogeographical elements and relics. Forest science, 1, 2018b, 23-38. (in Bulgarian)

8. Glogov, P., M. L. Georgieva, G. Popov, M. Bojilova, A. Delkov. Melliferous plants in the dendroflora of Lozenska Mountain. Proceeding paper 150 Years of Bulgarian Academy of Siences. Professor Marin Drinov Academic Publishing House., ISBN:978-619-245-001-4 (Online), 2019, 253-262. (in Bulgarian)

9. Glogov, P. M. L. Georgieva. Analysis of dendroflora on the territory of Lozen mountain. III Ecological structure. Forest science, 1, 2020 (in press). (In Bulgarian)

10. IUSS Working Group WRB, World Reference Base for Soil Resources 2014, update 2015. International soil classification system for naming soils and creating legends for soil maps. World Soil Resources Reports, FAO, Rome, 2015, No 106, p. 203.

11. Kosiński, P. Dendrofloristic regionalization of the Polish part of the Eastern Sudety mts. based on species similarity between basic spatial units Roczniki Akademii Rolniczej w Poznani. CCCL
XXII, Bot.-Stec., 8, 2005, 113-121.

12. Kurjakov, A, J. Čukanović, M. Blagojević, E. Mladenović, K. Hiel, S. Vukićević. Ecological Analysis of the Dendroflora of Futoški Park in the City of Novi Sad. Contemporary Agriculture. 66 (1-2), 2017, 7-13.

13. Ninov, N. Soils in Geography of Bulgaria. Vol 1. BAS, Sofia, 1997, 225-257. (In Bulgarian).

14. Pavlov, D. Phytocoenology. Publishing House University of forestry, Sofia, 2006, 252 p. (in Bulgarian).

15. Penkov, M., V. Donov, T. Boyadzhiev, T. Andonov, N. Ninov, M. Yolevski, G. Andonov, Sv. Gencheva, Classification and Diagnostics of Soils in Bulgaria in Relation to Land Divisions. Zemizdat SF, 1992, p. 151. (in Bulgarian).

16. Stefanov, B. Contribution to the investigation and classification of oak forests in Bulgaria. Ann. of Sofia University, XXI, Agronomy-and-Forestry Faculty, 1943, 2, 145 p. (in Bulgarian).

17. Tashev, A., E. Tzavkov. Dendroflora of the Pirin Mountain (Bulgaria) and Its Conservation Importance. 7th Planta Europa Conference 'Plants for people, People for Plants'. Horizon Research Publishing, USA, 2014, 105-111.

18. Velev, St. Climate division (in Bulgarian with English summary). In Yordanova, M. and Donchev, D. editors, Geography of Bulgaria. Physical geography. Socio-economic geography, Sofia: Publishing House of the Bulgarian Academy of Sciences, 1997, 269-283. (n Bulgarian).

19. Walter, H. Grundlagen der Pflanzenverbreitung. Stuttgart., 1954, $525 \mathrm{~s}$.

\section{Ch. Assist. Plamen Stankov Glogov, PhD Ch. Assist. Mira Lyubcheva Georgieva, PhD}

Forest Research Institute, Bulgarian Academy of Sciences 132 "Kliment Ohridski" Blvd 1756 Sofia, Bulgaria e-mails: plglogov@abv.bg mirageorgieva@abv.bg 